\title{
Imbibition, germination and cooking time of seeds of dry beans (Phaseolus vulgaris L.) stored in different containers'
}

\author{
Juan A. Jiménez," Dermot P. Coyne: and Freddy Saladin
}

\begin{abstract}
Deterioration of bean seed quality in storage is a problem for consumers, seed producers, and growers. Research was conducted to evaluate imbibition and germination of dry bean seed cultivars/lines stored under conditions similar to those used by small farmers in the Dominican Republic. Eight dry bean cultivars and lines were grown at three locations in the Dominican Republic. Seed samples were stored in jute bags, plastic containers, and metallic cans under uncontrolled conditions in a small wooden building with slatted shelves. Sub-samples of seeds were taken at 2, 4 and 6 months to determine changes in moisture content, imbibition and germination. Mean cooking time values were determined for seed of four cultivars which had been stored in the three types of above mentioned containers for 6 months. Seed moisture content decreased from 11 to $7 \%$ during 2 to 6 months of storage for 'Venezuela 44' and 'ICA-Pijao', respectively. Seed of 'Constanza' had the lowest imbibition value. Imbibition value differed among cultivars for seed stored in different container types. Germination of 'Venezuela 44 ' exceeded $90 \%$, but was only $66 \%$ for 'José Beta'. At 6 months, the germination viability of seed stored in jute bags and plastic confainers was $78 \%$ and $83 \%$, respectively, whereas seed stored in metallic containers was $92 \%$ viable. Seed of 'Venezuela 44 ' had shorter cooking times than seed of the other cultivars. Cooking time of seed differed among container types. Results indicate that growing location, cultivars, storage containers and duration of seed storage can affect seed quality of beans in the Dominican Republic.
\end{abstract}

\section{RESUMEN}

Imbibición, germinación y tiempo de cocción de la habichuela seca

(Phaseolus vulgaris L.) almacenada en diferentes envases

El deterioro de la calidad de la habichuela seca almacenada es un problema para productores, comerciantes y consumidores. El experimento que describimos se efectuó para evaluar la imbibición y la germinación de

'Published as Paper No. 8499, Journal Series, Nebraska Agriculture Research Division. Research was conducted under Project \#20-036 (Genetics, Breeding and Cultural Interactions of Dry Edible Beans). Part of thesis presented by Juan A. Jiménez ${ }^{2}$ to the Faculty of the Graduate College of the University of Nebraska in partial fulfillment of requirements for the Master of Science degree.

${ }^{2}$ Graduate student and Professor, Department of Horticulture, University of Nebraska, Lincoln, NE, respectively.

${ }^{3}$ Principal Investigator, Title XII Bean/Cowpea CRSP Project in the Dominican Republic. 
la semilla de habichuela almacenada en condiciones similares a las usadas por los pequeños agricultores en la República Dominicana.

Ocho genotipos de habichuela se cosecharon en tres localidades en la República Dominicana y se almacenaron en sacos de yute, envases plásticos o latas en un cuarto de madera en condiciones ambientales sin reguJar. Se fomaron submuestras a los 2, 4 y 6 meses de almacenamiento para determinar la humedad de la semilla, la imbibición y la germinación. Se tomó el tiempo de cocción de 4 de los genotipos de las semillas almacenados en los tres tipos de envases por 6 meses.

La humedad de la semilla de 'Venezuela 44' e 'ICA-Pijao' disminuyó de $11 \%$ a $7 \%$ al aumentar el tiempo de almacenamiento de 2 a 6 meses, respectivamente. La semilla de 'Constanza' tuvo el valor más bajo de imbibición, particularmente de la habichuela cosechada en Higüey y almacenada por 2 meses. La magnifud de la imbibición fue diferente, lo que se atribuye a las cultivares y tipos de envases. La germinación de Venezuela $44^{\prime}$ se mantuvo sobre $90 \%$ durante el almacenamiento, mientras que la de 'José Beta' se redujo a $66 \%$. La germinación disminuyó durante el almacenamiento, especialmente la de la semilla almacenada en sacos de yute por 6 meses. 'Venezuela $44^{\prime}$ se coció en menos tiempo que las ofras. El tipo de envase afectó el tiempo de cocción del grano. La localidad, cultivar, envase y tiempo de almacenamiento afectaron la calidad de la semilla.

\section{INTRODUCTION}

Dry beans (Phaseolus vulgaris L.) are of critical importance in many developing countries, serving as the principal source of protein and complementary protein in human diets (2). A survey performed by Cantizano (4) in a rural region in the Dominican Republic indicated that $93 \%$ of the families surveyed consumed beans daily. Sixty-five percent consumed from 50 to 75 grams daily, and $23 \%$ consumed less than 50 grams. Fiftyone percent of the people interviewed reported a reduction in the amount consumed due to low-quality beans because of hard, diseased and discolored seed (4). Reduction in seed quality in storage, even for a short time, creates problems for seed specialists, processors, growers and consumers.

Seed quality traits previously mentioned are a function of genotype (15), field environment at time of seed development and seed maturity (13), harvesting techniques and seed conditioning procedures, post-harvest cleaning and grading, and storage practices, all of which can produce physical and chemical changes in the seed (12). Several methods, including noncontrolled (14) and controlled $(6,9)$ storage conditions, have been used to study seed quality and deterioration. Seed hardness (17) has been reported to affect water absorption (9) and cooking time (9). Other factors, including type of beans, storage time (15), and storage conditions (3) can reduce germination viability of bean seed $(5,15)$.

Cantizano (4) reported that $63 \%$ of the surveyed families did not soak beans prior to cooking, whereas $26 \%$ soaked beans overnight. Research was needed to determine the effect of soaking time on moisture absorption of bean cultivars grown in the Dominican Republic. 
Although several studies have investigated factors affecting beanseed quality under different storage conditions, varying results have been reported. This possibly relates to variations in bean genotypes and production conditions. The objective of the present research was to determine the effects of commonly used storage containers, and the time of storage on the imbibition, quality, germination viability, and cooking time of discrete dry-bean cultivars produced in different field environments.

\section{MATERIALS AND METHODS}

Bean Production

The production phase was performed at three locations in the Dominican Republic. The cultivars and lines used and their place of origin were: 'Pompadour Checa' (DR), 'Constanza' (DR), 'José Beta' (DR), PC-50 (DR), BAT-1214 (CIAT), 'Venezuela 44' (Venezuela), 'ICA-Pijao' (Colombia), and 'Arroyo Loro \#I' (DR). The three locations were at Higüey, San Juan de la Maguana and Mao, representing the humid, arid, semiarid regions of the Dominican Republic. A randomized complete block design with four replications was employed. Each plot consisted of eight 5 -m long rows spaced $0.5 \mathrm{~m}$ apart. Single seed were planted $0.10 \mathrm{~m}$ apart within the rows. The beans were grown under locally used culture practices and were irrigated as needed. After harvesting, the seeds were sent to San Cristóbal where they were sun-dried for 3 days, or until moisture content was about $12 \%$.

Yields were low in two replications at San Juan, and in one replication at Mao. Accordingly, it was necessary to composite the seecls of each cultivar for all replications at each location, in order to obtain an adequate amount of seed of each cultivar and line for the storage exeriment.

\section{Storage Procedure}

Sacked beans were stored on slatted shelves, in a room $3 \mathrm{~m}$ long, 2.5 $\mathrm{m}$ wide and $3 \mathrm{~m}$ high, in a rain-proof wooden building. The building walls were covered with plywood and the roof with transite and ceiling tile. it was located at the CESDA Experimental Station at San Cristóbal, Dominican Republic. Such storage of beans in jute bags, in a rain-free wooden building, is a common practice among small farmers in the Dominican Republic. Controlled climate storage is not ordinarily practiced.

Seed samples, about $350 \mathrm{~g}$ for each cultivar/line, were stored in three types of containers: 1) jute bags $\left(3629 \mathrm{~m}^{3}\right)$; 2) plastic containers with tops $\left(1814 \mathrm{~m}^{3}\right)$; and 3) metallic cans with tops $\left(362.9 \mathrm{~m}^{3}\right)$. A split-split-split-block design was employed, in which storage containers served as whole plots, locations as sub-plots, and cultivars/lines as sub-sub-plots. For each location, four samples of seeds for cultivars or lines were randomly assigned 
and subsampled three times during storage as sub-sub-sub-plots (15) (table 1). The first storage experiment began 16 March 1986, and ended 28 August 1986. Temperature and relative humidity were neither controlled nor recorded.

\section{Sampling Procedure}

Three seed samples of 80 grams each per experimental unit were placed in sealed plastic bags, packed in boxes and shipped by air freight to Lincoln, Nebraska. Shipment dates were 12 May, 13 July and $28 \mathrm{Au}-$ gust 1986. Shipment time was about 11 days. Immediately after receipt of each shipment, the samples were treated for possible bruchid infestation (Zabrotes subfasciatus B.). An 80-g tablet of 'No-Pest Strip' insecticide, sufficient for 96 experimental units, was placed among the beans in a cardboard box sealed by means of a plastic bag. Treatment interval was 14 days.

\section{Moisture Content}

Bean sub-samples consisting of $20 \mathrm{~g}$ per experimental unit, were dried in a vacuum oven at $70^{\circ} \mathrm{C}$ for $60 \mathrm{~h}$. The seed moisture content was computed on an oven-dry basis.

\section{Water Uptake}

Sub-samples consisting of 40 seeds per experimental unit were weighed, soaked in $45 \mathrm{ml}$ distilled water for $8 \mathrm{~h}$ at room temperature $\left(22^{\circ} \mathrm{C}, \pm 1^{\circ}\right)$, and weighed again after soaking. The number of imbibed seeds was counted, with imbibition evidenced by swelling of the seeds. Water uptake was calculated by subtracting initial weight from final soaked weight, then dividing by initial weight.

In order to determine whether an 8-h soaking period was adequate for water uptake to facilitate cooking, an experiment was performed to measure the amount of water uptake over time. A split-plot design was used with two replications of the three types of storage containers as main plots, and cultivar/lines as sub-plots (16). Only beans from the Higüey site were used. Seed samples $(20 \mathrm{~g})$ were submerged in $45 \mathrm{ml}$ distilled water at room temperature. Emersion times were $0,4,8,12$, 16 , and $24 \mathrm{~h}$. The seeds were dried and weighed after each soaking period. The water uptake was calculated as previously stated.

Germination Procedure

One subsample consisting of 50 seeds was taken from each experimental unit. One seed was placed in each slot (same distance apart) on a 20 $\times 28 \mathrm{~cm}$ wooden counting board. The seeds were then dropped through the slots on top of a wetted standard paper $(20.5 \times 38 \mathrm{~cm})$ used for germination tests (1). The seed were then covered by a second similar wetted paper, and both papers and seeds were rolled together. The rolls 
TABLE 1.-Analysis of variance for dry bean storage parameters

\begin{tabular}{|c|c|c|c|c|c|}
\hline \multirow[b]{2}{*}{ Source of variation } & \multirow[b]{2}{*}{ df } & \multicolumn{4}{|c|}{ Mean squares for parameters } \\
\hline & & $\begin{array}{c}\text { Moisture } \\
\text { content } \\
\%\end{array}$ & $\begin{array}{c}\text { Germ- } \\
\text { ination } \\
\%\end{array}$ & $\begin{array}{l}\text { Imbibed } \\
\text { water }\end{array}$ & $\begin{array}{l}\text { Imbibed } \\
\text { seeds }\end{array}$ \\
\hline Total & 863 & & & & \\
\hline Container (Cont) & 2 & 0.003 & 0.16 & 0.74 & 0.11 \\
\hline Contrast:J vs $\mathrm{P}+\mathrm{M}^{2}$ & 1 & $0.007^{\mathrm{k} * 3}$ & 0.31 & $0.86^{*}$ & 0.19 \\
\hline$P$ vs $M$ & 1 & 0.000 & 0.01 & 0.61 & 0.02 \\
\hline Location (Loc) & 2 & $0.006^{*}$ & $2.92^{k * * 4}$ & $0.83 *$ & 0.30 \\
\hline \multicolumn{6}{|l|}{ Error A } \\
\hline (Cont $\times$ Loc) & 4 & 0.0007 & 0.168 & 0.120 & 0.433 \\
\hline Cultivar (Cult) & 7 & $0.001 *$ & $0.46^{* *}$ & $1.64^{* * * k}$ & $6.5^{* *}$ \\
\hline Cont $\times$ Cult & 14 & 0.000 & 0.30 & $0.10^{*}$ & $0.03^{*}$ \\
\hline Loc $\times$ Cult & 14 & 0.000 & $0.12^{3 * 11}$ & $0.12^{* * *}$ & $0.16^{* * *}$ \\
\hline \multicolumn{6}{|l|}{ Error B } \\
\hline (Cont $\times$ Loc $\times$ Cult $)$ & 28 & 0.00007 & 0.026 & 0.043 & 0.130 \\
\hline Time (Tim) & 2 & $0.330^{* *}$ & $2.74^{* * *}$ & $1.23^{* * *}$ & $0.59^{* *}$ \\
\hline Contrast: 2 vs $6^{5}$ & 1 & $0.530^{* * *}$ & $5.40^{4: 2}$ & 0.06 & $0.69^{* * *}$ \\
\hline Cont $\times$ Tim & 4 & $0.002^{*}$ & $0.55^{*}$ & $0.35^{*}$ & $0.17^{*}$ \\
\hline Contrast: (2vs 6) (Cont) & 2 & $0.003^{*: *}$ & 0.74 & $0.65^{\mathrm{s*} *}$ & $0.34 * *$ \\
\hline Loc $\times$ Tim & 4 & $0.004 *:$ & 0.07 & 0.03 & 0.05 \\
\hline \multicolumn{6}{|l|}{ Error C } \\
\hline$($ Cont $\times$ Loc $\times$ Tim $)$ & 8 & 0.003 & 0.125 & 0.055 & 0.029 \\
\hline Cult $\times$ Tim & 14 & $0.0002^{* *}$ & $0.04 *$ & $0.10^{k *}$ & $0.05^{*}$ \\
\hline Cont $\times$ Cult $\times$ Tim & 28 & 0.000 & 0.02 & $0.06^{*}$ & 0.02 \\
\hline Loc $\times$ Cult $\times$ Tim & 28 & 0.000 & 0.01 & $0.05^{*}$ & 0.01 \\
\hline \multicolumn{6}{|l|}{ Error D } \\
\hline$($ Cont $\times$ Loc $\times$ Cult $\times$ Tim $)$ & 56 & 0.00006 & 0.016 & 0.029 & 0.019 \\
\hline
\end{tabular}

'ANOVA was run with arcsin (SQRT) transformed arithmetic means, except for water imbibed.

${ }^{2} \mathcal{J}=$ jute bags, $P=$ plastic containers, $M=$ metallic cans.

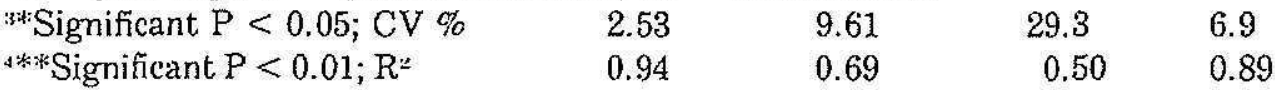

" 2 and 6 months of storage.

and seeds were then transferred to an incubator at $80 \% \mathrm{Rh}$ and $25^{\circ} \mathrm{C}$ $\left( \pm 1^{\circ}\right)$ temperature. The number of germinated seeds was recorded 6 days later. Seeds which did not germinate, or which produced deformed seedlings, were regarded as nongerminated.

Cooking Time

Samples for cooking time consisted of 12 seeds from each of four varieties ('Pompadour Checa', 'José Beta', 'BAT-1214', and 'Venezuela $\left.44^{\prime}\right)$. Each of the three production sites and storage containers was represented. The cooking tests were performed 20 days after the imbibition 
and germination trials. At that time, bean moisture content ranged from 7.0 to $7.4 \%$. A split-split-block design was employed with locations as main blocks, types of storage containers as sub-plots, and cultivars/lines as sub-sub-plots.

Two bean samples were soaked for $4 \mathrm{~h}$ in distilled water at $45^{\circ} \mathrm{C}$. They were placed in a modified Mattson Bean Cooker $(8,11)$. The latter was positioned in a pot containing 4.5 liters of boiling distilled water. Initial cooking time was recorded at the moment the cooking device was placed in boiling water. Total cooking time was recorded as initial, intermediate and maximum intervals determined by the cooking-instrument design $(8,11)$.

\section{RESULTS AND DISCUSSION}

Seed Moisture

The moisture content of dry bean seeds varied with growing locations and with length of storage time (table 1). Moisture content of San Juan samples decreased from $11.6 \%$ at 2 months in storage, to $10.6 \%$ at 4 months (table 2). No seed moisture change was detected from Higüey and Mao for these storage intervals. However, for all locations, moisture decreased to $7.2 \%$ by the end of 6 -month storage (table 2). Muneta (14) reported seed moisture variations up to $5 \%$ as a function of location. Bean seed moisture content could have been affected by environmental conditions during the growing and harvesting season, soil characteristics, and by harvest and post-harvest handling.

Bean moisture content also differed in relation to types of storage containers and their duration in storage. Moisture values declined from $11.1 \%$ to $9.8 \%$ for beans stored in plastic containers at 2 and 4 months, respectively (table 2). No significant reduction in seed moisture was noted for seeds stored in jute bags and metallic cans for these periods. Moisture decreased to $7 \%$ between months 4 and 6 , but there were no significant differences between containers. The moisture values for the small, black-seeded 'Venezuela 44' and 'ICA-Pijao' cultivars and for white-seeded 'Arroyo Loro \#1' declined from 11.3, 11.2 and $11.1 \%$ to $10.6,10.5$ and $10.7 \%$, respectively, at 2 to 4 month storage (table 3 ). The larger-seeded pinto cultivars did not lose moisture during the same periods. Hosfield and Uebersax (7) reported differences in moisture content of tropical black beans, as compared to tropical non-black varieties. Physical and structural characteristics of dry bean cultivars might affect moisture content as storage time is extended.

\section{Germination}

Germination varied as a function of cultivars/lines and location. Germination for Higüey ranged from 94 to $96 \%$, and from 80 to $90 \%$ for San Juan and Mao, respectively. Germination was low for 'José Beta', amounting only to $66 \%$. 
TABLE 2.-Means of dry bean storuge parumeters

\begin{tabular}{|c|c|c|c|c|c|c|c|c|c|c|c|}
\hline \multirow{2}{*}{$\frac{\text { Container' }}{\text { Jute }}$} & \multirow{2}{*}{$\frac{\begin{array}{c}\text { Time } \\
\text { months }\end{array}}{2}$} & \multicolumn{2}{|c|}{ \%oisture } & \multicolumn{2}{|c|}{$\%$ Germination } & \multicolumn{2}{|c|}{$\begin{array}{c}\text { Imbibed seed } \\
\text { number }\end{array}$} & \multirow{2}{*}{$\frac{\text { Location: }}{1}$} & \multirow{2}{*}{$\frac{\begin{array}{c}\text { Time } \\
\text { months }\end{array}}{2}$} & \multicolumn{2}{|c|}{ \% Moisture } \\
\hline & & $0.33^{*}$ & $(10.8)^{1}$ & $1.42^{3}$ & $(96.3)^{4}$ & $1.44^{3}$ & $(38.0)^{x}$ & & & $0.33^{3}$ & $(10.6)^{4}$ \\
\hline & 4 & 0.33 & $(10.7)$ & 1.39 & $(92.2)$ & 1.49 & (39.1) & 1 & 4 & 0.33 & (10.4) \\
\hline & 6 & 0.28 & $(7.7)$ & 1.11 & $(78.5)$ & 1.45 & (38.4) & 1 & 6 & 0.27 & $(7.2)$ \\
\hline \multirow{3}{*}{ Plastic } & 2 & 0.34 & (11.1) & 1.41 & (95.6) & 1.45 & (38.3) & 2 & 2 & 0.35 & (11.6) \\
\hline & 4 & 0.32 & $(9.8)$ & 1.36 & $(93.5)$ & 1.47 & $(38.6)$ & 2 & 4 & 0.33 & $(10.6)$ \\
\hline & 6 & 0.27 & $(7.0)$ & 1.19 & $(83.2)$ & 1.39 & $(37.6)$ & 2 & 6 & 0.27 & (7.2) \\
\hline \multirow[t]{3}{*}{ Metallic } & 2 & 0.33 & $(10.7)$ & 1.38 & $(94.4)$ & 1.48 & $(39.1)$ & 3 & 2 & 0.32 & $(10.0)$ \\
\hline & 4 & 0.32 & $(9.8)$ & 1.32 & $(92.0)$ & 1.46 & $(38.6)$ & 3 & 4 & 0.33 & $(10.3)$ \\
\hline & 6 & 0.27 & $(7.1)$ & 1.32 & $(92.1)$ & 1.32 & $(36.7)$ & 3 & 6 & 0.27 & $(7.3)$ \\
\hline LSD 0.05 & & 0.01 & & 0.08 & & 0.04 & & & 0.01 & & 0.01 \\
\hline
\end{tabular}

'Container: jute bags, plastic containers, metallic cans.

"Location: 1 = Higüey, $2=\operatorname{San}$ Juan, $3=$ Mao.

"Arcsin (SQRT) transformed arithmetic mean.

"Arithmetic mean.

LSD value applies only to transformed data. 
TABLE 3.-Mean values for dry bean storage parameters

\begin{tabular}{|c|c|c|c|c|c|c|c|}
\hline \multirow{2}{*}{$\frac{\text { Cultivar }}{\text { Pompadour Checa }}$} & \multirow{2}{*}{$\begin{array}{c}\begin{array}{c}\text { Time } \\
\text { months }\end{array} \\
2\end{array}$} & \multicolumn{2}{|c|}{$\begin{array}{c}\text { Moisture } \\
\%\end{array}$} & \multicolumn{2}{|c|}{$\underset{\% / c}{\text { Germination }}$} & \multicolumn{2}{|c|}{$\begin{array}{c}\text { Imbibed seed } \\
\text { number }\end{array}$} \\
\hline & & $0.33^{\prime}$ & $(10.5)^{:}$ & $1.40^{\prime}$ & $(95.6)^{2}$ & $1.55^{\prime}$ & $(38.8)^{2}$ \\
\hline & 4 & 0.33 & $(10.5)$ & 1.34 & $(92.7)$ & 1.56 & $(39.9)$ \\
\hline & 6 & 0.27 & $(7.4)$ & 1.21 & $(84.4)$ & 1.49 & (39.6) \\
\hline \multirow[t]{3}{*}{ Constanza } & 2 & 0.33 & $(10.4)$ & 1.42 & $(96.5)$ & 0.89 & $(30.4)$ \\
\hline & 4 & 0.32 & $(10.2)$ & 1.30 & $(89.8)$ & 0.92 & $(31.0)$ \\
\hline & 6 & 0.27 & $(7.1)$ & 1.21 & $(85.2)$ & 0.70 & $(24.6)$ \\
\hline \multirow[t]{3}{*}{ José Beta } & 2 & 0.33 & $(10.5)$ & 1.28 & $(90.2)$ & 1.53 & $(39.7)$ \\
\hline & 4 & 0.33 & $(10.5)$ & 1.22 & $(85.2)$ & 1.55 & $(39.9)$ \\
\hline & 6 & 0.27 & $(7.1)$ & 0.98 & $(69.4)$ & 1.45 & $(39.2)$ \\
\hline \multirow[t]{3}{*}{ PC-50 } & 2 & 0.33 & $(10.7)$ & 1.36 & $(90.0)$ & 1.55 & (39.7) \\
\hline & 4 & 0.32 & $(10.3)$ & 1.30 & $(90.0)$ & 1.56 & $(39.9)$ \\
\hline & 6 & 0.27 & $(7.3)$ & 1.19 & $(83.2)$ & 1.52 & (39.7) \\
\hline \multirow[t]{3}{*}{ BAT-1214 } & 2 & 0.33 & $(10.6)$ & 1.46 & $(97.8)$ & 1.50 & $(39.6)$ \\
\hline & 4 & 0.32 & $(10.4)$ & 1.36 & $(94.5)$ & 1.53 & (39.7) \\
\hline & 6 & 0.27 & $(7.1)$ & 1.20 & $(84.6)$ & 1.38 & (38.7) \\
\hline \multirow{3}{*}{ Venezuela 44} & 2 & 0.34 & $(11.3)$ & 1.46 & (97.1) & 1.54 & (39.8) \\
\hline & 4 & 0.33 & $(10.6)$ & 1.38 & $(94.5)$ & 1.56 & (39.8) \\
\hline & 6 & 0.27 & (7.4) & 1.31 & $(91.2)$ & 1.51 & (39.6) \\
\hline \multirow{3}{*}{ ICA-Pijao } & 2 & 0.34 & (11.2) & 1.40 & $(96.2)$ & 1.56 & $(40.0)$ \\
\hline & 4 & 0.33 & $(10.5)$ & 1.36 & $(93.2)$ & 1.57 & $(40.0)$ \\
\hline & 6 & 0.27 & $(7.4)$ & 1.29 & (91.3) & 1.52 & (39.7) \\
\hline \multirow[t]{3}{*}{ Arroyo Loro \#1 } & 2 & 0.34 & (11.1) & 1.44 & $(96.8)$ & 1.56 & (39.9) \\
\hline & 4 & 0.33 & $(10.7)$ & 1.33 & (91.6) & 1.55 & (39.9) \\
\hline & 6 & 0.27 & $(7.2)$ & 1.25 & $(87.3)$ & 1.54 & $(39.9)$ \\
\hline "LSD 0.05 & & 0.004 & & 0.06 & & 0.08 & \\
\hline
\end{tabular}

Delouche and Baskin (5) reported significant differences in percent germination incident to different seed lots. Germination as function of variety and location might vary because of injury at harvest and in postharvest management. Physical and chemical composition might also be contributing factors. With reference to insects, cultivar 'José Beta' was more severely damaged by bruchids than any other cultivar. This was especially true for beans from San Juan. This may be due to the softer seed of 'José Beta', permitting greater ease of penetration and emergence of the insect. ${ }^{5}$

${ }^{5} \mathrm{~F}$. A. Bliss, personal communication. 
Germination was also affected by storage as a varietal factor. A large decrease in germination occurred in seeds stored for 4 to 6 months, especially for 'José Beta' (16\% reduction), whereas only slight decreases occurred in 'Venezuela 44' (3\%) and 'ICA-Pijao' (2\%). Differences in seed structures among cultivars could account for these changes. Percentages of germination and moisture experienced similar patterns of decline. Samples bearing only about $7 \%$ moisture might have been approaching a lower critical moisture level.

\section{Imbibition}

Imbibition ratios varied as a function of cultivars/lines, location, and duration of storage. The ratio for 'Constanza' (0.31), from the Higüey location, was materially lower than that of San Juan (0.56) and Mao (0.51) when stored for 2 months. It was also lower than 'Constanza' stored for 4 and 6 months. Seeds of 'Venezuela 44' and 'ICA-Pijao' from Higüey at 6 months of storage had a greater ratio than the seeds of the other cultivars under the same conditions, except for seeds of 'Arroyo Loro \#1' which showed no change due to location or storage duration.

Imbibed water also varied with cultivars/lines, types of storage containers, and storage duration (table 1). Ratios for 'Constanza', stored in jute bags for 2 and 4 months, and in metallic cans for 6 months, were lower than for any other cultivar stored in any of the three types of containers. Comparatively higher ratios were obtained for BAT-1214, 'Venezuela 44' and 'ICA-Pijao'. Ratios for Higüey samples also varied with cultivars and containers.

The gain in seed weight of 'ICA-Pijao' after soaking seeds for 4, 8, and 12 hours was greater than for the 'Pompadour Checa', 'Constanza', and BAT-1214 which had been stored previously in jute bags or plastic containers (fig. 1). The gain in seed weight of 'ICA-Pijao' was nearly similar for seeds stored in jute bags or plastic containers. 'Constanza' showed the least gain in seed weight after soaking seeds from both storage containers, in comparison with the other bean entries during this same period. The gain in weight of seed after soaking for 4, 8 and 12 hours was greater for seeds of the 'Pompadour Checa', BAT-1214, and ICA-Pijao, which had been stored previously in jute bags. These results suggest that soaking bean seeds for 4 to 8 hours would be useful to evaluate bean cultivars or lines for seed hardness after periods in storage. However, a long soaking period (16 hours) is recommended to prepare beans for cooking since at that time the seed weight gain of the different varieties is similar, except for seeds of 'Constanza' which had been stored in plastic containers. 'ICA-Pijao' need only be soaked for 8 hours for cooking since the weight gain at 8 hours is similar to the gain at $12,16,20$ or 24 hours. 


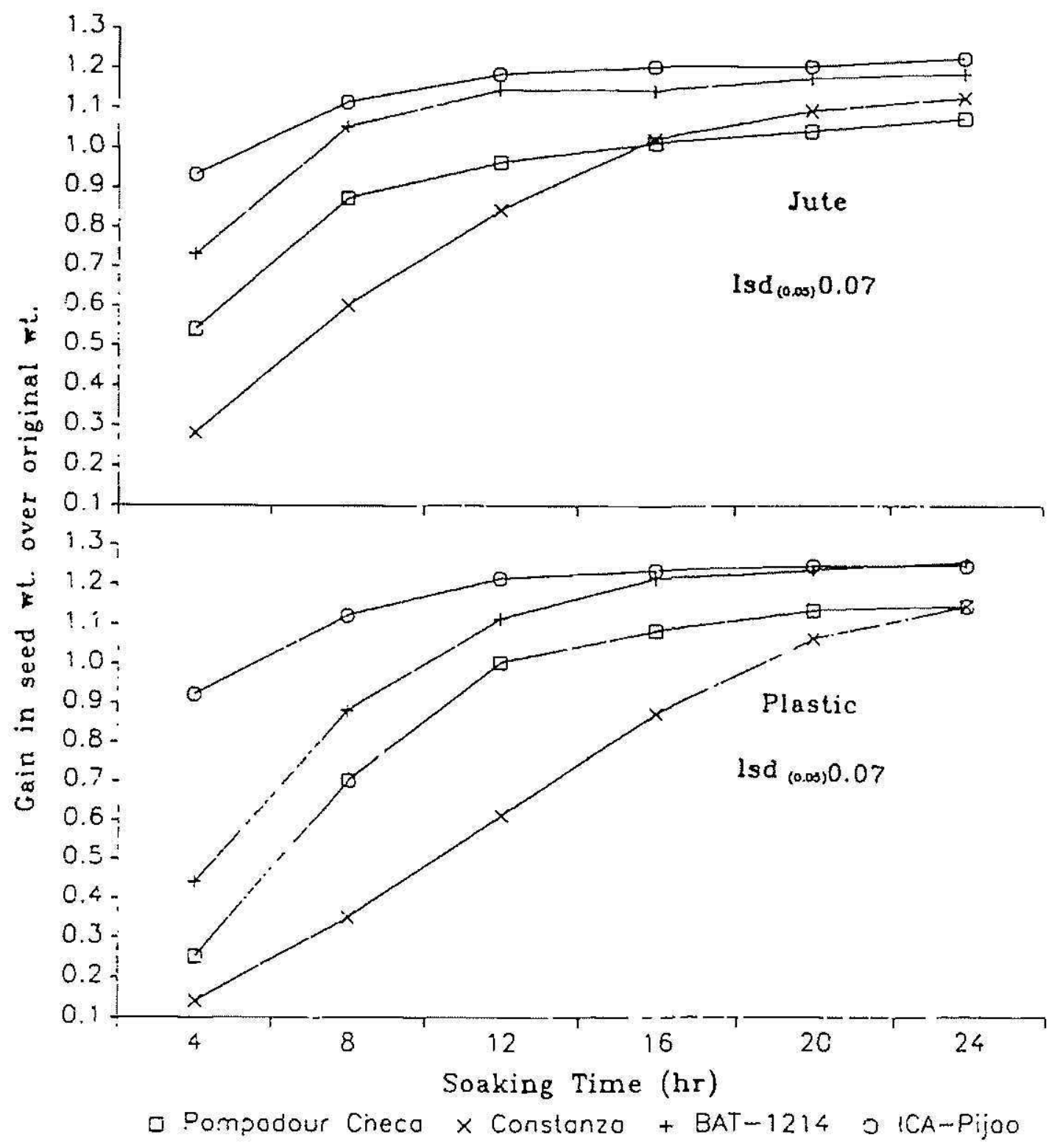

Frg. 1.-Seed weight increase during 24 hour soaking, for four bean cultivars stored in jute bags and plastic containers.

Cooking Test

Cultivars and storage containers affected the intermediate and maximum cooking times of seeds (table 4 ). The high hydration capacity and low cooking times for 'Venezuela 44' seem to be associated, indicating that imbibition is related to shorter cooking times. Maeda (11) and Jones and Boulter (9) indicated that rapidly imbibed beans generally cook faster than the slower imbibed seeds.

In conclusion, simple and practical storage systems need to be developed for small farmers in developing tropical countries. It is of great importance for a rural family to preserve good quality bean seed for 
TABLE 4.-Wean coaking time values for dry beans given different storage containers

\begin{tabular}{llccc}
\hline Cultivar & Container & Initial & Intermediate & Maximum \\
\hline & & - & & \\
Pompadour Checa & Jute & 67 & 99 & 128 \\
José Beta & & 67 & 92 & 122 \\
BAT-1214 & & 65 & 90 & 118 \\
Venezuela 44 & & 50 & 78 & 102 \\
Pompadour Checa & Plastic & 62 & 89 & 115 \\
José Beta & & 70 & 105 & 131 \\
BAT-1214 & & 63 & 85 & 110 \\
Venezuela 44 & & 50 & 74 & 97 \\
Pompadour Checa & Metallic & 67 & 89 & 115 \\
José Beta & & 63 & 94 & 117 \\
BAT-1214 & & 47 & 95 & 125 \\
Venezuela 44 & & NS & 10.6 & 92 \\
\hline LSD 0.05 & & & 12.8 \\
\hline
\end{tabular}

'Initial, intermediate, and maximum is time when first, sixth and twelfth bean was cooked as indicated by Mattson cooker.

consumption and for propagation. The effect of environmental parameters in different production areas on the quality of seed of bean cultivars should be further examined in the Dominican Republic to determine the most suitable areas for production. Such information would be valuable to seed agencies, farmers, and consumers.

\section{LITERATURE CITED}

1. Anonymous, 1952. Manual for testing agricultural and vegetable seeds. Agric. Handb. No. 30. USDA, Washington, DC, USA.

2. Bressani, R., 1985. Protein quality and nutritional value of beans. Research Highlights, Michigan State University Bean/CRSP, INCAP/Washington State University/ Swanson. Vol. 2: (6).

3. Burr, H., S. Kon and $\mathrm{H}$. Morris, 1968. Cooking rates of dry bean as influenced by moisture content and temperature, and time of storage. Food Technology 22: 336-38.

4. Cantizano, M., 1985. Resultados encuesta aplicada a productores de la Provincia de San Juan de la Maguana, Municipio de Vallejuelo. Santo Domingo, D.N., República Dominicana. $76 \mathrm{p}$.

5. Delouche, J. and C. Baskin, 1973. Accelerated aging techniques for predicting the relative storability of seed lots. Seed Sci. Technol. 1: 427-52.

6. Dester, S., A. Anderson, P. Fahler and E. Benne, 1955. Responses of white pea beans to various humidities and temperature of storage. Agron. J. 74: 246-50.

7. Hosfield, G. and M. Uebersax, 1980. Variability in physico-chemical properties and nutritional components of tropical and domestic dry bean germplasm. J. Am. Soc. HortSci. 105 (2): 246-52.

8. Jackson, G. and E. Varriano-Marston, 1981. Hard-to-cook phenomenon in beans: Effect of accelerated storage on water absorption and cooking time. J. Food Sci. 46: 799803. 
9. Jones, M. and D. Boulter, 1983. The cause of reduced cooking rate in Phaseolus vulgaris following adverse storage conditions. $J$. Food Sci. 48: 623-26.

10. Korban, S., D. Coyne and J. Weihing, 1981. Rate of water uptake and sites of water entry in seeds of different cultivars of dry bean. HortSci. 16 (4): 545-46.

11. Maeda, E. and S. Rocke, 1986. Screening bean cultivars for cookability. Presented in Bean/Cowpea CRSP workshop, Washington State University, Pullman WA 15-18, 1985.

12. McDonald, M. and C. Nelson (Eds), 1986. Physiology of seed deterioration. Crop Sci. Soc. of Amer. Inc., Madison, Wisconsin, USA, p 121.

13. Magalhães, A., A. Millar and E. Choudhury, 1979. Efeito do déficit de agua sobre a produção de feijao. Turrialba 29 (4): 269-73.

14. Muneta, P., 1964. The cooking time of dry beans after extended storage. Food Technol. 18: $1240-241$.

15. Rayas, P., L. Sánchez, C. Wong, B. Romero, A. González and O. Vidal, 1982. Influence of temperature and relative humidity on the germination, hydration capacity, hardshell, and color of two varieties of beans (Phaseolus vulgaris) stored in pilot silos. Presented in the 42nd Annual Institute of Food Technology Meeting, Las Vegas, June 22-25, 1982.

16. Steel, R. and J. Torrie, 1980. Principles and Procedures of Statistics (2nd ed). McGrawHill Book Company.

17. Swanson, B., J. Hughes and P. Rasmussen, 1985. Seeds microstructure: Review of water imbibition in legumes. Department of Food Sci. and Human Nutrition, and Horticulture and Landscape Architecture. Washington State Univ., Pullman WA, 99164-6330. 